\title{
Reworked Eocene-Oligocene dinoflagellate cysts in the Miocene of the Carpathian Foredeep Basin: implications for Paleogene palaeogeography in SE Poland
}

\author{
Przemysław GEDL
}

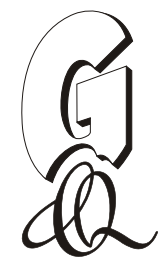

Gedl P. (2012) - Reworked Eocene-Oligocene dinoflagellate cysts in the Miocene of the Carpathian Foredeep Basin: implications for Paleogene palaeogeography in SE Poland. Geol. Quart., 56 (4): 853-868, doi: 10.7306/gq.1059

\begin{abstract}
Miocene strata of the Carpathian Foredeep Basin in Poland contain reworked Eocene and Oligocene dinoflagellate cysts, which come from two sources: the Flysch Carpathians and the epicontinental basin. The occurrence of the latter is almost the only trace of the epicontinental Eocene-Oligocene sedimentary cover, which extended across southwestern Poland, and is today nearly completely eroded. The distribution of epicontinental Eocene and Oligocene taxa in the Miocene strata of the northeastern part of the Carpathian Foredeep is uneven, clearly pointing to a limited extent of the host deposits and their variable erosion intensity. Erosion of the Eocene and Oligocene platform cover took place prior the Miocene transgression and took place also during the Badenian; its intensity increased during Late Badenian-Sarmatian tectonic movements, resulting in an increased frequency of reworked specimens in strata postdating the mid-Badenian deposits.
\end{abstract}

Przemystaw Gedl, Institute of Geological Sciences, Polish Academy of Sciences, Senacka 1, 31-002 Kraków, Poland, e-mail: ndgedl@cyf-kr.edu.pl (received: June 20, 2012; accepted: August 10, 2012; first published online: November 27, 2012).

Key words: dinoflagellate cysts, reworking, epicontinental Paleogene, palaeogeography, SE Poland.

\section{INTRODUCTION}

Marine Eocene and Oligocene deposits of the NW and central European epicontinental sea are well recognized in northern Poland and the extent of these marine basins has been precisely reconstructed (Fig. 1). Rich micropalaeontological assemblages allow the distinction of several transgression events and their links with neighbouring basins. However, southeastwards the documentation of Eocene and Oligocene marine deposits becomes scarce (see Krzowski, 1993). This is due to non-continuous cover of these strata, which south of the northern margin of the Lublin Upland they occur as isolated occurrences only (e.g., Piwocki, 2004; Fig. 1). Additionally, a scarcity of microfossil did not allow for their precise dating and correlation.

Dinoflagellate cysts are commonly present in the fragmentarily preserved Eocene-Oligocene deposits of SE Poland (Gedl, 2000a). Following the erosion of these, reworked dinoflagellate cysts in the Miocene deposits of the Carpathian Foredeep are often the only traces of the Eocene and Oligocene marine deposits of SE Poland.

Earlier palynological studies of the Miocene of the Polish Carpathian Foredeep Basin revealed the presence of dinofla- gellate cysts (Macko, 1957; Kita, 1963). However, these studies focused mainly on pollen, while dinoflagellate cysts were described superficially. Moreover, no precise taxonomical studies were conducted, commonly referring these assemblages to the Hystrichosphaeridae only. This meant that no difference between in situ and reworked forms was noted in these earlier papers. Hence, palaeoenvironmental reconstructions made on the basis of such dinoflagellate cyst assemblages might have been erroneous since they very likely also included reworked taxa (see e.g., Kita, 1963, p. 520). More recent studies of dinoflagellate cysts from the Miocene of the Polish Carpathian Foredeep Basin (e.g., Gedl, 1995, 1996a, 1997a, 2005a; Peryt and Gedl, 2010) distinguished between Miocene forms and the ones reworked from pre-Miocene strata. Moreover, various stages of preservation of the reworked specimens made it possible to distinguish their source of origin: less well-preserved, commonly darker-coloured specimens were derived from Carpathian strata, whereas the pale-coloured ones came from epicontinental deposits. However, many Paleogene species, especially the Oligocene ones, are also known from Miocene. This pertains to several species representing genera such as: Spiniferites, Operculodinium, Systematophora, Reticulatosphaera, Selenopemphix, Hystrichokolpoma, etc., which commonly occur in the Miocene strata of 


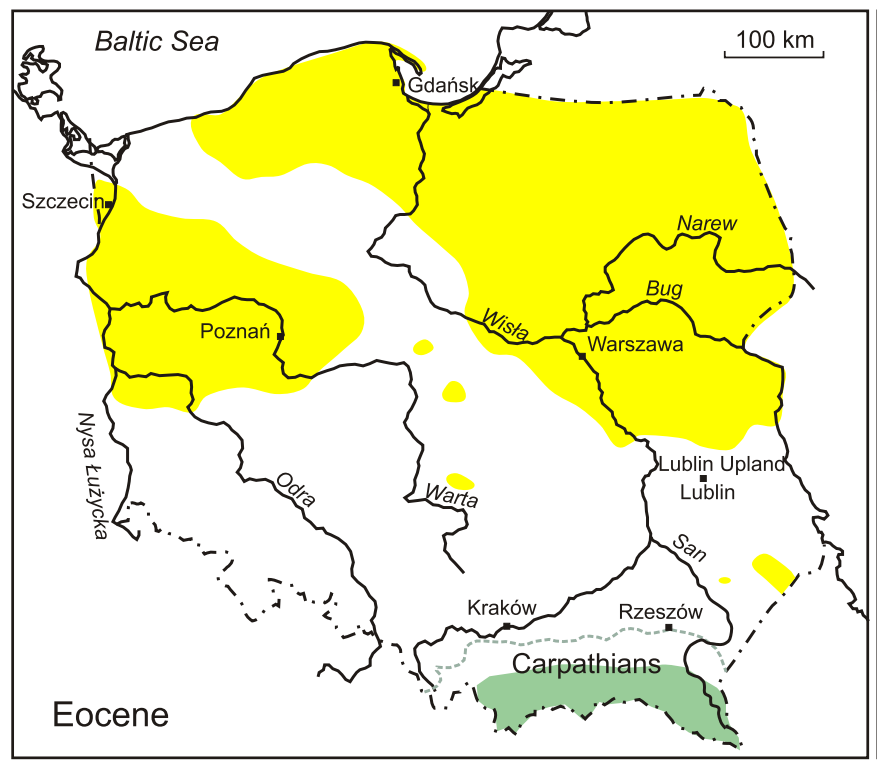

epicontinental deposits

Carpathian deposits

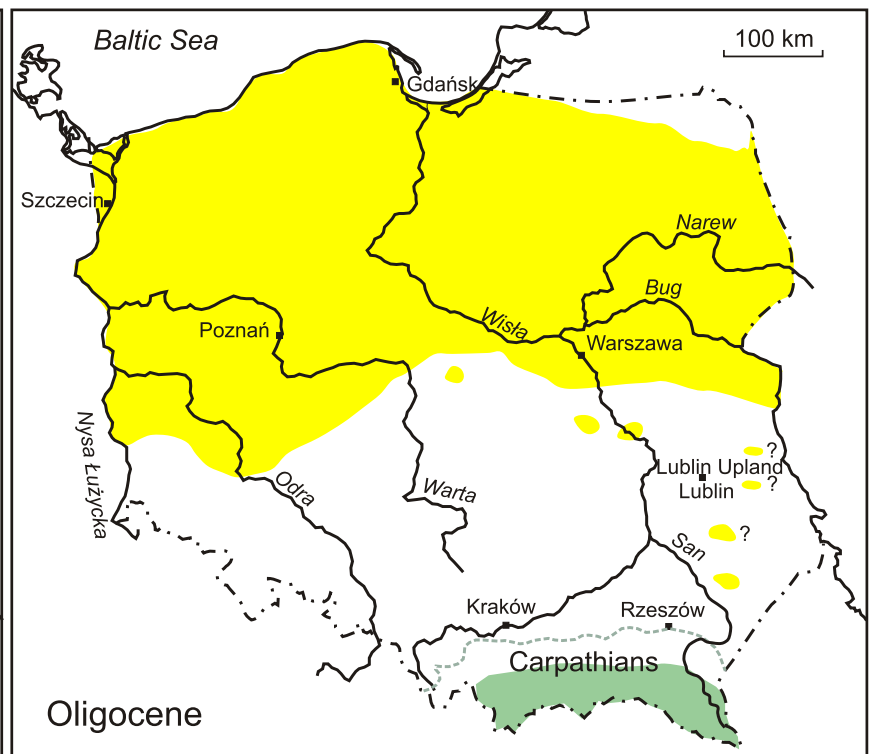

present-day extent of overthrusted Carpathian nappes

Fig. 1. Present-day extent of Eocene and Oligocene deposits in Poland (based on Piwocki, 2004; supplemented by data from Odrzywolska-Bieńkowa et al., 1978; Grabowska and Słodkowska, 1993; Gedl, 2000a; Słodkowska, 2004; Myśliwiec and Śmist, 2006)

Dotted line indicates extent of Carpathian nappes, which due to overthrusting were moved up to 50 km northwards (see Kotlarczyk, 1985)

the Carpathian Foredeep Basin. Since their similar state of preservation does not allow for the distinction reworked forms from those in situ, only these species which have known stratigraphical ranges limited to the Paleogene will be considered as "reworked" (e.g., Wetzelielloideae). In this paper new data on reworked Eocene and Oligocene dinoflagellate cysts from Miocene deposits in the Polish Carpathian Foredeep Basin are presented. They are compared with previously published data. Although the distribution of reworked dinoflagellate cysts in Miocene strata is related to several factors (e.g., sedimentation mode, erosion intensity, drainage system pattern) it may also provide significant evidence towards the palaeogeographical reconstruction of the varying extent of the Paleogene seas in SE Poland.

\section{GEOLOGICAL SETTING}

During the Paleogene, the northwestern and central European epicontinental sea extended from the North Sea through northern Germany and Poland to Belarus and Ukraine (e.g., Ziegler, 1978). In Poland, the most complete Eocene and Oligocene succession is known from northern Poland (Fig. 1). But there also, it contains frequent hiatuses, and particular lithostratigraphic units are of small thickness and commonly of local occurrence (e.g., Piwocki, 2004). Lower Eocene deposits are known from northwestern Poland only. Bartonian-Priabonian deposits have a broader distribution: they occur in north and northeastern Poland. Rupelian deposits consist of continental and marine strata. The youngest is the Chattian Leszno Formation known from western Poland only (Piwocki, 2004).

The southeastern boundary of palaeontologically well-documented Eocene deposits runs approximately along the northern peripheries of the Lublin Upland. In this area the Bartonian-Priabonian Siemień Formation has been documented (e.g., Woźny, 1966; Po aryska and Locker, 1971;
Uberna and Odrzywolska-Bieńkowa, 1977; Uberna, 1981; Kosmowska-Ceranowicz and Po aryska, 1984; Kasiński and Tołkanowicz, 1999). Słodkowska (2004) documented Mid-Late Eocene phytoplankton from the Wisła River valley at a similar latitude. Sandy-glauconitic deposits known from isolated sites on the Lublin Upland are palaeontologically barren. These have been traditionally regarded as Oligocene in age but Krzowski (1993), on the basis of radiometric K-Ar dating of glauconite, suggested their Mid-Late Eocene age. Marine Eocene deposits with micropalaeontologically documented ages have been recently documented from Roztocze (the so-called Sołokija Graben Eocene: e.g., Cieśliński and Rzechowski, 1993; Buraczyński and Krzowski, 1994; Gaździcka, 1994) and the Carpathian Foredeep (Łukowa 4 borehole: Myśliwiec and Śmist, 2006; Fig. 1). These two isolated sites with Eocene deposits occur in the area which, according to Piwocki (2004), was a land barrier (Bohemian-Małopolska-Ukrainian massifs) separating Carpathian basins from the epicontinental sea.

The situation is similar with the Oligocene deposits, which are widely distributed north of the Lublin Upland (Piwocki, 2004); south of this region, only isolated sites with marine Rupelian deposits are known from the Carpathian Foredeep (Tarnogród area: e.g., Gedl, 2000a; Myśliwiec and Śmist, 2006; Fig. 1). The position of these deposits is enigmatic: in the light of palaeogeographic reconstructions, the Oligocene epicontinental deposits of Poland are linked with transgressions from the west (Piwocki, 2004).

\section{MATERIAL}

Material for the present study comes from several sites within the Carpathian Foredeep (Fig. 2), which include both boreholes and exposures. Below, a brief description is provided. 


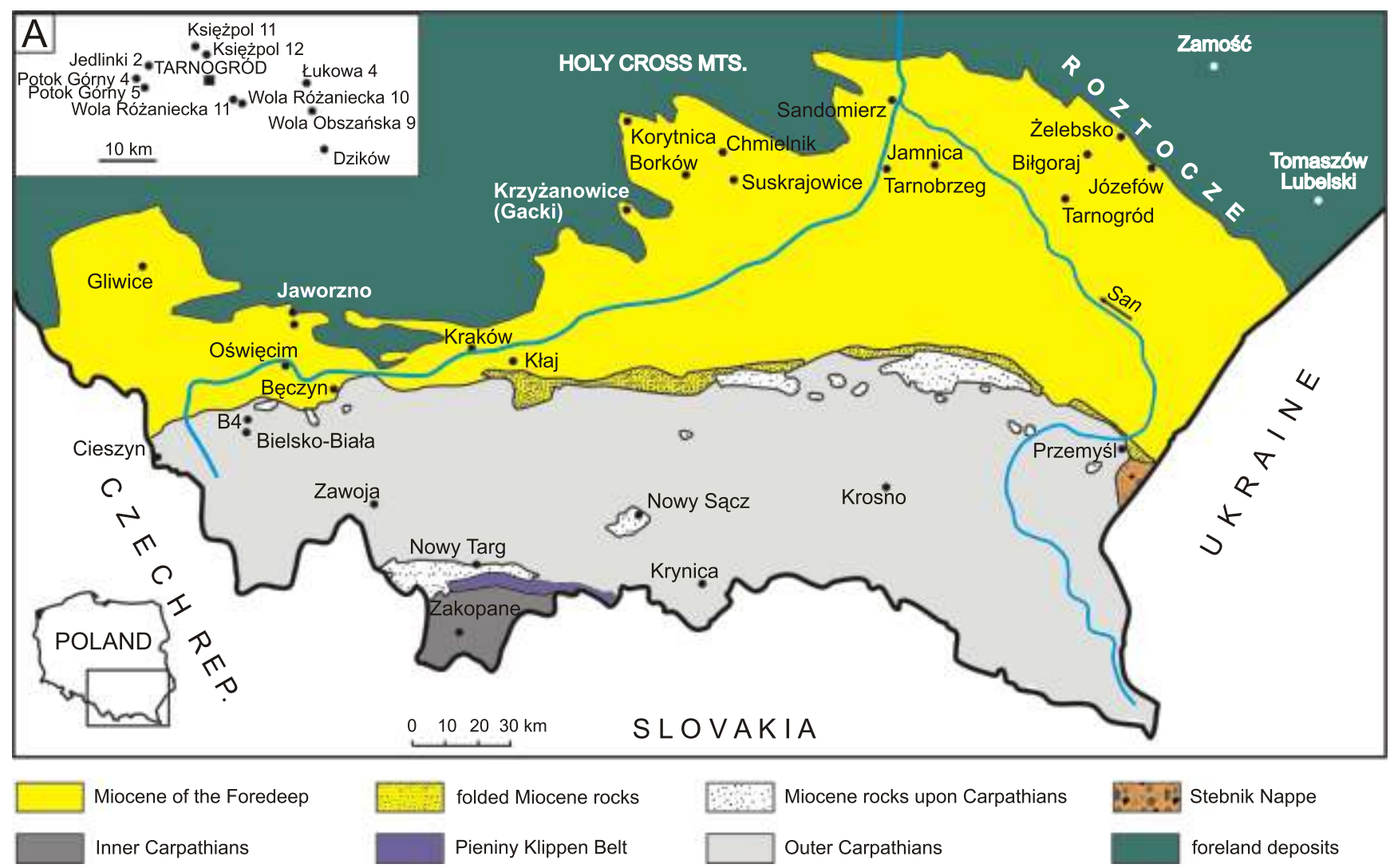

Fig. 2. Geological sketch of the Miocene Carpathian Foredeep with locations of sites studied

A - location of boreholes in the Tarnogród vicinity (after Myśliwiec and Śmist, 2006)

Since the lithostratigraphical division of the Miocene of the Carpathian Foredeep is still not uniform, local names for particular lithostratigraphic units are followed (for discussion of their correlation see Olszewska, 1999 and Jasionowski et al., 2004).

\section{SOUTHWESTERN PART OF THE POLISH FOREDEEP BASIN, BELOW THE CARPATHIAN OVERTHRUST}

Konior and Krach (1964) described from the B4 borehole (ca. $5 \mathrm{~km}$ north of Bielsko-Biała; Fig. 2) the basal interval of the Miocene succession, which occurs there below the Dębowiec conglomerate (depth $1549.65 \mathrm{~m}$ ). The lowermost part of this succession consists of brownish-grey sandstones, which pass upwards into whitish sandstones (1679-1721 m). Higher up, Konior and Krach (1964) distinguished dark non-calcareous mudstone with abundant macrofauna and brown coal layers; these two lithological units were included by Kuciński et al. (1975) in the Hałcnów Formation. Samples for dinoflagellate cysts were taken from the 1661.8-1668.2 m interval developed as dark mudstone with brown coal intercalations passing upwards into a richly fossiliferous non-calcareous mudstone.

\section{KRAKÓW-OŚWIECIM AREA}

The Miocene between Kraków and Oświęcim consists of the Lower-Middle Badenian Skawina Beds, the Middle Miocene Wieliczka Formation and the Upper Badenian Chodenice and Grabowiec Beds (e.g., Ksią kiewicz, 1951; Alexan- drowicz, 1958, 1961, 1963; Ney, 1968; Łuczkowska, 1995). Several boreholes in this area have been studied as regards dinoflagellate cysts (see Pilarz, 2012; Appendix 1).

A complete sequence of Miocene near the margin of the Carpathian overthrust was drilled by the Kłaj 1 borehole (Fig. 2). It penetrated almost $800 \mathrm{~m}$ of Miocene, which rests there on Upper Cretaceous marls (Stemulak, 1955 fide Kita, 1963; see also Kirchner, 1956; Olewicz, 1973; Łuczkowska, 1978). Palynology from this succession was studied by Kita (1963). 57 samples were studied for dinoflagellate cysts: 18 samples from the Skawina Beds (interval 733-842 m) and 39 samples from the upper part of the Chodenice Beds and basal part of the Grabowiec Beds (374-632 m).

Additional material was collected by the author from artificial exposures of the Skawina Beds and mid-Badenian evaporites exposed during construction work in Kraków.

\section{NORTHERN MARGIN OF THE FOREDEEP BASIN (SOUTH OF THE HOLY CROSS MTS.)}

The Middle Miocene succession south of the Holy Cross Mts. starts with Badenian marine strata (e.g., Radwański, 1969), which locally rest on the continental Trzydnik Formation sensu Alexandrowicz et al. (1982; clastic deposits with lignite seams) or directly on eroded Cretaceous and Jurassic rocks. It includes the Lower Badenian Pińczów Formation, which consists of various, commonly locally developed, informal lithostratigraphic units (e.g., the Korytnica Clays and the Baranów Beds; 
Kowalewski, 1930; Bałuk and Radwański, 1977, 1979, 1984; Jasionowski, 1997; Czapowski, 2004), the Middle Badenian Krzy anowice Formation (evaporites), the Upper Badenian marls and marly clays with intercalations of sands and limestones, and the youngest Chmielnik Formation (Alexandrowicz et al., 1982), which includes the so-called "detrital Sarmatian". The age of the Chmielnik Formation is Lower Sarmatian (e.g., Czapowski and Studencka, 1990, 1996). The following sites from this area were studied for dinoflagellate cysts:

- the Korytnica Clays are locally underlain by continental strata developed as green non-calcareous clay and dark-coloured organic-rich non-calcareous clay (see e.g., Bałuk and Radwański, 1977; Szymanko and Wójcik, 1982). The thickness of these strata is variable; it reaches a maximum of $70 \mathrm{~m}$ (Szymanko and Wójcik, 1982). Material from these strata obtained from shallow boreholes at Niziny was studied for palynology;

- an abandoned quarry at Krzy anowice near Pińczów (also known as the Gacki Quarry) exposed a complete Badenian succession composed of Lower Badenian fine-grained marly deposits underlying the Middle Miocene Krzy anowice Formation and overlying clays (Alexandrowicz and Parachoniak, 1956; Łuczkowska, 1974). Seven samples come from clays overlying the evaporitic horizon, and a single sample from clays underlying the gypsum;

- several outcrops of the "detrital Sarmatian" are known from the Chmielnik vicinity (see Rutkowski, 1976; Czapowski and Studencka, 1990). These generally coarse-grained deposits contain occasional thin intercalations of fine-grained material, sampled for dinoflagellate cysts at an exposure at Suskrajowice.

\section{NORTHEASTERN MARGIN OF THE POLISH FOREDEEP BASIN}

The northeastern part of the Carpathian Foredeep Basin was characterized by bimodal facies development, especially during the post-evaporitic period. This was due to the diverse tectonic history of this part of the basin: the marginal zone was then mainly uplifted (the present-day Roztocze area; see below) whereas the basinal part was predominantly downwarped (Oszczypko, 1996; Krzywiec, 2001; Wysocka, 2002, 2006a). As a consequence, the latter area is characterized by a thick (up to $2000 \mathrm{~m}$ ) sequence of fine-grained, loamy-silty deposits.

Several boreholes examined for dinoflagellate cysts in the Biłgoraj-Tarnogród area penetrated the Miocene sequence that is over $1 \mathrm{~km}$ thick in this region (see Myśliwiec and Śmist, 2006; Fig. 2A; Appendix 1). It rests upon Mesozoic-Paleozoic to pre-Paleozoic rocks, and consists of the Lower Badenian Baranów Beds (2-3 m, maximum 10 m thick), evaporitic deposits (about $20 \mathrm{~m}$ - Peryt et al., 1998) and approximately $1000 \mathrm{~m}$ of post-evaporitic heterolithic deposits. In a few boreholes, packages several metres thick of marine Paleogene deposoits have been found (Gedl, 2000a). Fourteen boreholes have been analyzed for reworked Paleogene dinoflagellate cysts (Appendix 1).

\section{ROZTOCZE}

The Miocene of the Roztocze area represents a marginal facies of the Carpathian Foreland basin. During the Badenian marine transgression, which entered this region, it represented an uplifted area in relation to the central part of the basin (e.g., Ney et al., 1974). A different sedimentary setting in this marginal zone resulted in a much thinner Miocene sequence (several to a few tens of metres compared to almost $2000 \mathrm{~m}$ in the basinal part) consisting generally of shallow-marine sands, marls and organodetrital limestones (see e.g., Buraczyński, 1997). Three sites in Roztocze area were studied, located in two quarries at Józefów and in a quarry at elebsko. The Upper Badenian exposed in these sites consists chiefly of sandy organodetrital limestone (calcarenite to calcirudite; see Wysocka, 2002, 2006b; Wysocka et al., 2006; Jasionowski et al., 2006). Within these coarse-grained deposits rare fine-grained layers occur; these were sampled for dinoflagellate cysts.

\section{PREVIOUS STUDIES}

Previously published data on reworked Eocene and Oligocene dinoflagellate cysts include studies from: the western part of the Foredeep Basin (Gliwice area: Gedl, 1997a); the southwestern part of the Foredeep Basin, below the Carpathian overthrust (Zawoja 1 borehole: Gedl, 1997b, Gedl in Oszczypko et al., 2000); Kraków-Oświęcim area (Bęczyn: Gedl, 2005a; boreholes at Trzebinia: Gedl, 1995); the southern surrounds of the Holy Cross Mts. (Korytnica: Gedl, 1996a; quarry at Borków: Peryt and Gedl, 2010); and the northeastern margin of the Foredeep Basin (Jamnica S119 borehole: Gedl, 1999).

Individual specimens of very well-preserved pale-coloured specimens (Areosphaeridium diktyoplokum, Chiropteridium sp., Charlesdowniea sp., Deflandrea heterophlycta, Wetzeliella sp.) were found in Lower Badenian clays of the Baranów Beds that underlie the Krzy anowice Formation in the Borków Quarry (Fig. 2; Peryt and Gedl, 2010).

Reworked Paleogene taxa, characterized by pale colours and a good state of preservation, occur throughout the whole sequence of the over 250 metres deep Jamnica S119 borehole (Fig. 2; Gedl, 1999). Areoligera coronata, Enneadocysta pectiniformis, Homotryblium pallidum occur in the Baranów Beds (sample 274.5-276.5 m). The lower part of the Pecten Beds yielded rather infrequent reworked specimens (sample 257-258 m: Charlesdowniea clathrata, Fibrocysta sp., Wetzeliella symmetrica; samples 250.5 and $253 \mathrm{~m}$ : Charlesdowniea clathrata, Enneadocysta pectiniformis, Homotryblium sp.). These are also rare in the lowermost part of the Krakowiec Clays (sample 236.03-236.06 m: Deflandrea heterophlycta, Enneadocysta pectiniformis; sample 234.09-234.1 m: Deflandrea phosphoritica). The higher part of this lithostratigraphic unit contains reworked specimens (including Cretaceous species), which appear to be more common than the Miocene ones (interval 208.5-228.17 m: Areosphaeridium diktyoplokum, Deflandrea phosphoritica, Glaphyrocysta sp., Homotryblium sp., Rhombodinium longimanum, Wetzeliella $\mathrm{sp}$.). In the upper part of the Krakowiec Clays (interval 36-120 m), Paleogene forms are al- 
most the only dinoflagellate cysts (Areosphaeridium diktyoplokum, Enneadocysta pectiniformis, Deflandrea phosphoritica, Glaphyrocysta sp., Homotryblium plectilum, Homotryblium sp., Thalassiphora pelagica, Wetzeliella gochtii, W. symmetrica subsp. incisa). In this interval, much less well-preserved, dark-coloured specimens of Carpathian origin occur; they appear together with pale-coloured epicontinental ones.

\section{METHODS}

The samples were processed in the Micropalaeontological Laboratory of the Institute of Geological Sciences, Polish Academy of Sciences, Kraków. The standard palynological procedure applied included $38 \%$ hydrochloric-acid $(\mathrm{HCl})$ treatment, $40 \%$ hydrofluoric-acid (HF) treatment, heavy-liquid $\left(\mathrm{ZnCl}_{2}+\mathrm{HCl}\right.$; density $\left.2.0 \mathrm{~g} \mathrm{~cm}^{-3}\right)$ separation, ultrasound for $10-15 \mathrm{~s}$ and sieving at $10 \mu \mathrm{m}$ on a nylon mesh. No nitric-acid $\left(\mathrm{HNO}_{3}\right)$ treatment was applied.

The quantity of rock processed was $20 \mathrm{~g}$ for each sample. Thin sections were made from each sample using glycerine jelly as a mounting medium. The rock samples, palynological residues and slides are stored in the collection of the Institute of Geological Sciences, Polish Academy of Sciences, Kraków.

\section{RESULTS}

Samples from the Lower?-lower Middle? Miocene of the B4 borehole near Bielsko-Biała contain no reworked Paleogene dinoflagellate cysts (Fig. 3); samples of mudstone with coal intercalations appeared to be barren, whereas samples of fossiliferous mudstone contain assemblage of the latest Early to earliest Middle Miocene.

Similarly, samples collected from the Trzebinia borehole as well as from the man-made exposures in Kraków (sub-evaporitic deposits and evaporites) yielded no reworked Paleogene specimens. The Skawina Beds contain typical offshore dinoflagellate cyst assemblages (see Gedl, 1995) with various admixtures of terrestrial organic particles, whereas anhydrites from Kurdwanów (southern suburbs of Kraków) yielded a palynofacies consisting of dominant pollen grains and aquatic algae Leiosphaeridia.

Among 15 samples from 6 boreholes from the Kraków-Oświęcim area only a single sample from borehole Chełm 7 yielded reworked Paleogene dinoflagellate cysts (Fig. 3). A sample from depth $33 \mathrm{~m}$ (Chodenice Beds) contains poorly preserved, dark-coloured specimens (Wetzeliella sp., Homotryblium tenuispinosum, Deflandrea sp., associated with a Cretaceous Oligosphaeridium sp.); their preservation suggests that they derive from the Carpathians.

The Miocene sequence from the Kłaj 1 borehole yielded frequent reworked Paleogene dinoflagellate cysts (Fig. 3). Generally, only the basal part of the Skawina Beds (823-842 m) contains no reworked forms; higher up, these forms occur in various amounts. They consist of predominantly Paleogene taxa (e.g., Homotryblium, Lanternosphaeridium, Deflandrea and Wetzeliella) and subordinate Cretaceous ones (e.g., Cribroperidinium, Oligosphaeridium and Odontochi- tina). The highest ratio of reworked specimens occurs in the sub-evaporitic interval (374-632 m) where they commonly occur more frequently than do the in situ specimens. All reworked specimens from the Kłaj 1 borehole are dark-coloured and moderately to poorly preserved. These preservational features suggest that they derive from eroded Carpathian nappes.

Miocene sites south of the Holy Cross Mts. yielded various amounts of reworked Eocene-Oligocene dinoflagellate cysts. Presumed continental deposits at Niziny contain no dinoflagellate cysts. A single sample from fine-grained deposits that underlie the chemical deposits at Gacki yielded a typical taxonomically diverse assemblage of Badenian dinoflagellate cysts; only very rare reworked Paleogene specimens were found (Deflandrea spp., Dracodinium? sp.). More frequent Paleogene taxa, although subordinate to the in situ ones, occur in clays above the evaporitic succession. They are represented by Deflandrea (co-occurring with reworked Cretaceous taxa). All reworked specimens are pale-coloured and have intact wall structure showing their origin from the epicontinental basin.

Much more common are Paleogene dinoflagellate cysts, which occur in clay laminae from "detrital Sarmatian" deposits exposed at Suskrajowice. These are pale-coloured, but commonly mechanically damaged specimens of Wetzeliella, Deflandrea and incomplete gonyaulacoids; Paleogene taxa represent $100 \%$ of the determinable forms.

A Miocene sequence over $1 \mathrm{~km}$ thick in the Biłgoraj-Tarnogród area locally rests on marine Oligocene strata (Gedl, 2000a; see also Myśliwiec and Śmist, 2006). The basal part of the Miocene succession below the anhydrite horizon (Baranów Beds, locally including the Lithothamnium marl) usually contains no Paleogene dinoflagellate cysts (Potok Górny 4, Dzików 15, 17, Wola Obszańska 9, Jedlinki 2, Wola Ró aniecka 11, Księ pol 10, 11 - for boreholes location see Fig. 2A). The Baranów Beds from Potok Górny 4, Jedlinki 2, and Księ pol 11 rest directly on Oligocene strata. Individual reworked specimens have been found in the sub-anhydrite strata in the boreholes Wola Ró aniecka 7 (Deflandrea phosphoritica) and 10 (Areosphaeridium diktyoplokum) only. In some wells, anhydrite yielded infrequent Paleogene specimens, which represent the only dinoflagellate cysts from chemical deposits (Potok Górny 5: Homotryblium sp.; Sucha Wola 1: Deflandrea sp., Operculodinium microtriainum; Dzików 12: Areosphaeridium diktyoplokum; Jedlinki 2: Homotryblium pallidum).

The frequency of reworked Eocene-Oligocene dinoflagellate cysts increases in the supra-evaporitic heterolithic deposits. Although its basal part, i.e., strata just above the anhydrite horizon (Spirialis Clays), yielded rather rare reworked specimens (Jedlinki 2, Wola Ró aniecka 7, 10 boreholes) but higher parts contain much frequent Paleogene specimens, which commonly represent most of the dinoflagellate cyst assemblages (Table 1).

Fine-grained intercalations of generally coarse-grained organodetrital (mainly coralline algae) limestones of the Upper Badenian of Roztocze yielded common Eocene dinoflagellate cysts. This refers to samples collected from the Józefów quarries - the sample from the elebsko Quarry contains no reworked forms. The Eocene dinoflagellate cyst assemblage there consists of chorate gonyaulacoids: Adnatosphaeridium multispinosum, 

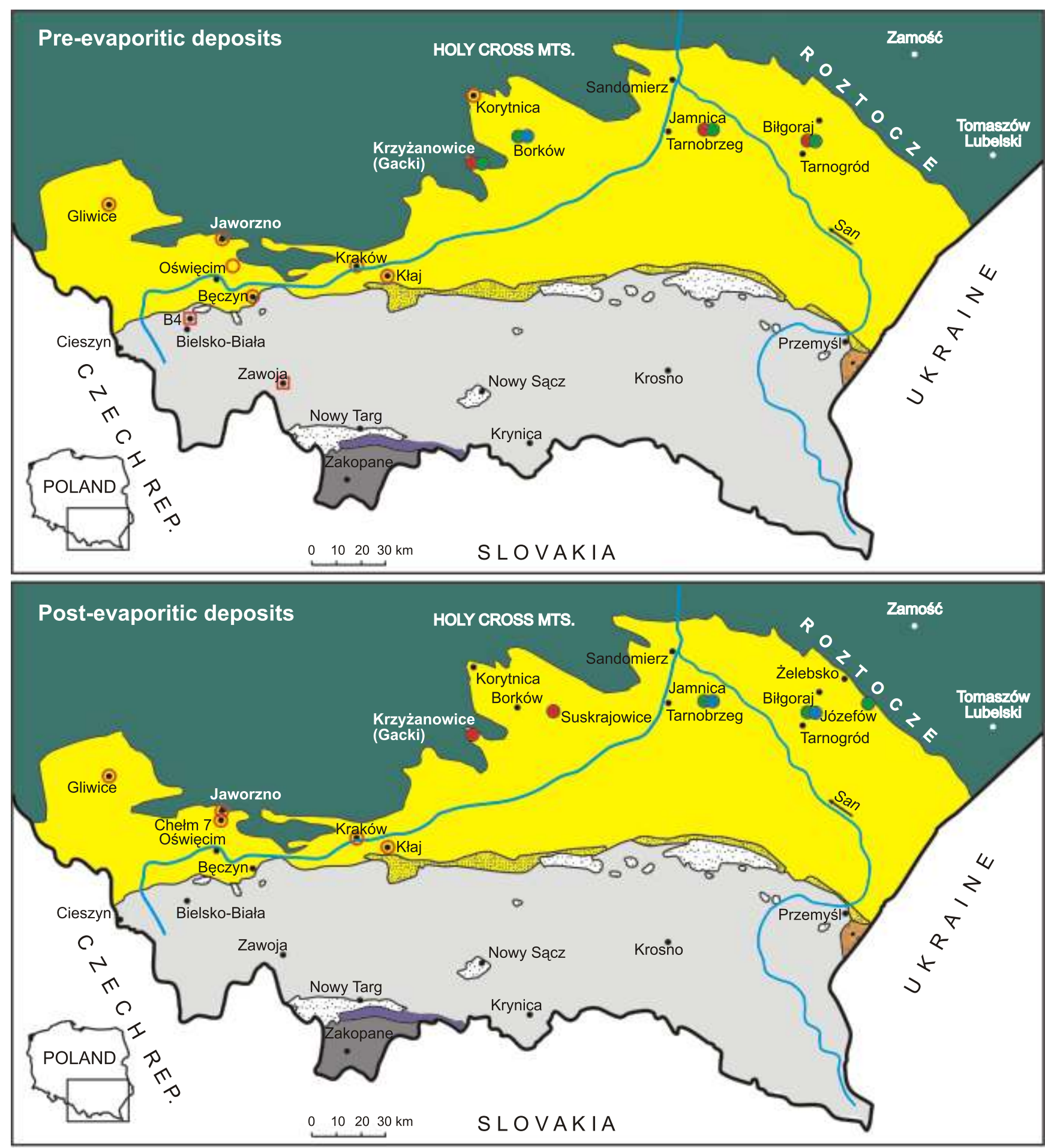

Middle Miocene deposits without reworked epicontinental Paleogene dinoflagellate cysts

$\square$ Lower Miocene deposits without reworked epicontinental Paleogene dinoflagellate cysts
Eocene-Oligocene reworked epicontinental dinoflagellate cysts

Eocene reworked epicontinental dinoflagellate cysts

Oligocene reworked epicontinental dinoflagellate cysts

Fig. 3. Occurrence of reworked epicontinental Eocene-Oligocene dinoflagellate cyst specimens in the Miocene of the Carpathian Foredeep 
Occurrence of reworked Eocene-Oligocene dinoflagellate cysts in the supra-evaporitic deposits of the Tarnogród area

\begin{tabular}{|c|c|c|c|c|c|c|c|c|c|c|c|c|c|c|c|}
\hline \multirow[b]{2}{*}{ 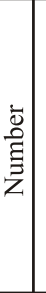 } & \multirow[b]{2}{*}{ Species } & \multicolumn{14}{|c|}{ Borehole } \\
\hline & & 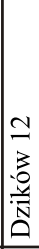 & 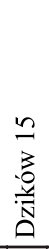 & 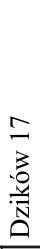 & $\stackrel{\sim}{\vec{z}}$ & 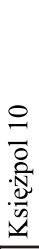 & 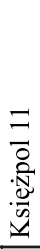 & 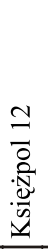 & 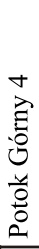 & 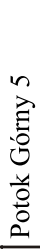 & $\begin{array}{l}- \\
\frac{\pi}{0} \\
3 \\
\frac{\pi}{0} \\
\frac{\pi}{0} \\
\bar{n}\end{array}$ & 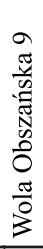 & 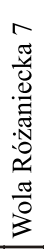 & 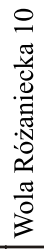 & 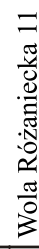 \\
\hline 1 & Apectodinium homomorphum & & $\mathrm{x}$ & & & & & & & & & & & & \\
\hline 2 & Areoligera sp. & & & & & & & & & & & & & $\mathrm{x}$ & \\
\hline 3 & Areoligera/Glaphyrocysta sp. & & & & & & & & & & & $\mathrm{x}$ & & & \\
\hline 4 & Areosphaeridium diktyoplokum & & $\mathrm{x}$ & & & & & & & & & & & & \\
\hline 5 & Charlesdowniea sp. & & & & & & & & & $\mathrm{x}$ & & & $\mathrm{x}$ & & \\
\hline 6 & Cordosphaeridium cantharellum & & $\mathrm{x}$ & & & & & & & $\mathrm{x}$ & & $\mathrm{x}$ & & & \\
\hline 7 & Cordosphaeridium inodes & $\mathrm{x}$ & & & & & & & & & & & & $\mathrm{x}$ & \\
\hline 8 & Cordosphaeridium sp. & & & & & & $\mathrm{x}$ & & & & & & & & \\
\hline 9 & Deflandrea heterophlycta & $\mathrm{x}$ & & & & & & & & & & & & & \\
\hline 10 & Deflandrea phosphoritica & & & $\mathrm{x}$ & $\mathrm{x}$ & & & & $\mathrm{x}$ & $\mathrm{x}$ & & & & & \\
\hline 11 & Deflandrea sp. & $\mathrm{x}$ & & & & $\mathrm{x}$ & $\mathrm{x}$ & $\mathrm{x}$ & $\mathrm{x}$ & $\mathrm{x}$ & $\mathrm{x}$ & $\mathrm{x}$ & $\mathrm{x}$ & & \\
\hline 12 & Enneadocysta multicornuta & & $\mathrm{x}$ & & & & & & $\mathrm{x}$ & & & & & & \\
\hline 13 & Glaphyrocysta pastielsii & & & & & & & & & & $\mathrm{x}$ & & & & \\
\hline 14 & Glaphyrocysta sp. & & & & & $\mathrm{x}$ & & & & & & $\mathrm{x}$ & & & \\
\hline 15 & Homotryblium pallidum & & & & & & & & $\mathrm{x}$ & $\mathrm{x}$ & $\mathrm{x}$ & & & & \\
\hline 16 & Homotryblium plectilum & & & & $\mathrm{x}$ & & & & $\mathrm{x}$ & & $\mathrm{x}$ & & & & \\
\hline 17 & Homotryblium tenuispinosum & & & & & & & & & & $\mathrm{x}$ & & & & \\
\hline 18 & Homotryblium sp. & $\mathrm{x}$ & $\mathrm{x}$ & $\mathrm{x}$ & $\mathrm{x}$ & $\mathrm{x}$ & $\mathrm{x}$ & $\mathrm{x}$ & $\mathrm{x}$ & $\mathrm{x}$ & & $\mathrm{x}$ & $\mathrm{x}$ & $\mathrm{x}$ & $\mathrm{x}$ \\
\hline 19 & Hystrichokolpoma cinctum & & & & & & & & & & & $\mathrm{x}$ & & & \\
\hline 20 & Membranophoridium aspinatum & & & & & & & & $\mathrm{x}$ & & & $\mathrm{x}$ & & & \\
\hline 21 & Operculodinium microtriainum & & & & & & & & $\mathrm{x}$ & & & & & & \\
\hline 22 & Rhombodinium draco & & & $\mathrm{x}$ & & & & & $\mathrm{x}$ & $\mathrm{x}$ & & & & & \\
\hline 23 & Wetzeliella articulata & & & & & & & & $\mathrm{x}$ & & & & & & \\
\hline 24 & Wetzeliella gochtii & & & & & & & & & & $\mathrm{x}$ & & & & \\
\hline 25 & Wetzeliella symmetrica & & & & & & & & $\mathrm{x}$ & & $\mathrm{x}$ & & & & \\
\hline 26 & Wetzeliella sp. & & & & $\mathrm{x}$ & & & $\mathrm{x}$ & & & & $\mathrm{x}$ & & $\mathrm{x}$ & \\
\hline
\end{tabular}

Areoligera sp., ?Areosphaeridium michoudii, Areosphaeridium diktyoplokum, Cordosphaeridium gracile, Enneadocysta sp., ?Enneadocysta arcuata, Glaphyrocysta spp., Homotryblium tenuispinosum, Membranophoridium aspinatum.

\section{INTERPRETATION}

\section{AGES OF REWORKED EPICONTINENTAL ASSEMBLAGES}

Most of the taxa treated here as reworked (i.e., having their last appearances pre-Miocene) are rather long-lived, typical of both the Eocene and Oligocene. Some other taxa such as Homotryblium and Deflandrea are also known from Lower Miocene strata (e.g., Dybkjær, 2004). The occurrence of Homotryblium in the Middle Miocene of the Foredeep was treated by Gedl (2005a) as reworked despite some other authors reporting its occurrence from Middle or even Upper Miocene strata (e.g., Köthe and Piesker, 2007; for discussion see de Verteuil and Norris, 1996).
The westernmost assemblages of reworked epicontinental Paleogene dinoflagellate cysts, in Borków and Gacki quarries, include species which represent both Eocene and Oligocene taxa. The occurrence of Areosphaeridium diktyoplokum in samples from Borków suggests erosion of Middle-Upper Eocene deposits since the stratigraphic range of this species is Middle-Late Eocene (e.g., Stover et al., 1996). However, the presence of Chiropteridium sp. in material from Borków points also at a younger, Oligocene source. This genus is known to appear for the first time during the Early Oligocene. Remaining taxa from Borków (Charlesdowniea sp., Deflandrea heterophlycta, Wetzeliella sp.), as well as those from Gacki (Deflandrea spp., Dracodinium? sp.) may represent both Eocene and Oligocene, although the latter genus is more typical of the Eocene.

Common reworked peridinioids that occur in Sarmatian deposits at Suskrajowice (Deflandrea phosphoritica and broken specimens of the Wetzeliella articulata-symmetrica complex) cannot date this assemblage more precisely than Eocene-Oligocene.

A similar, Eocene-Oligocene date can be applied to the majority of the samples studied from the Jamnica S119 borehole. 
A reworked assemblage from the Baranów Beds includes Enneadocysta pectiniformis (Priabonian-Rupelian; Stover and Williams, 1995) and Areoligera coronata (Senonian-Middle Eocene; Eaton, 1976). Another assemblage, containing Charlesdowniea clathrata, was found in strata directly above the evaporitic horizon (the Pecten Beds: 244-258 m). This species, known to have appeared during the latest Ypresian-early Rupelian (Stover et al., 1996), co-occurs in a sample from 257-258 $\mathrm{m}$ depth with Wetzeliella symmetrica (Bartonian-Chattian; Stover et al., 1996), and with Enneadocysta pectiniformis in a sample at $250.5 \mathrm{~m}$. The Priabonian-Rupelian age of the reworked dinoflagellate cyst assemblages from the basal part of the Krakowiec Clays can be established on the basis of the presence at Enneadocysta pectiniformis presence. Eocene species (Areosphaeridium diktyoplokum, Rhombodinium longimanum; Powell, 1992) occur in the higher part of the Krakowiec Clays in the Jamnica S119 borehole, indicating erosion of Eocene strata. The upper part of the Krakowiec Clays yielded, in turn, typical Oligocene species (Wetzeliella gochtii: Rupelian - Powell, 1992; W. symmetrica subsp. incisa: Oligocene - Gerlach, 1961) and the Eocene species (Areosphaeridium diktyoplokum).

"Paleogene-bearing" samples from the Biłgoraj-Tarnogród area contain assemblages, which do not allow precise dating. Most of the reworked specimens are of Eocene-Oligocene species. Only in a few samples do Areosphaeridium diktyoplokum (Dzików 15), typical of the Eocene, and Wetzeliella gochtii (a Rupelian species; Sucha Wola 1) occur.

An outstanding assemblage of reworked Paleogene dinoflagellate cysts was found in Józefów. It consists of gonyaulacoid chorate specimens only; the presence of Areosphaeridium michoudii suggests Middle-Late Eocene age for this assemblage (Bujak and Mudge, 1994).

\section{SPATIAL AND TEMPORAL DISTRIBUTION} OF REWORKED EPICONTINENTAL FORMS

The data presented above show a varied distribution of reworked Eocene-Oligocene dinoflagellate cysts in the Miocene of the Carpathian Foredeep (Fig. 3). The most common specimens are dark-colourated and are believed to represent forms, which originate from the overthrusted Carpathians (Fig. 4G-J; e.g., Gedl, 1996b, 1997b, 2004, 2005b) and reflect thermal maturity acquired during folding - this feature allows distinction them from epicontinental specimens, which although commonly mechanically damaged, show no increased thermal maturity. This interpretation is supported by their spatial occurrence: Carpathian specimens occur most frequently in the southern part of the Polish Carpathian Foredeep, where they appear in olistoliths (e.g., Zawoja 1 borehole; Gedl, 1997b, Gedl in Oszczypko et al., 2000) or in Miocene clays (e.g., Kłaj 1, Bęczyn; Gedl, 2005a) near the Carpathian overthrust (Fig. 3). The distribution of Carpathian specimens in the Miocene of the Foredeep is also controlled by palaeogeographic conditions and the timing of Carpathian overthrusting, but this problem is beyond the scope of the present paper.

Pale-coloured, thermally unaltered specimens of Eocene-Oligocene dinoflagellate cysts (Fig. 4A-F), treated here as derived from epicontinental deposits, occur exclusively in the northeastern part of the Foredeep, in both sub- and su- pra-evaporitic strata (Fig. 3). No reworked Paleogene dinoflagellate cysts have been found in Miocene strata from the western part of the Polish Foredeep Basin (Gliwice area; Gedl, 1997a), whereas exclusively Carpathian-derived reworked forms occur in the southwestern part of the Polish Foredeep Ba$\sin$ (Gedl, 1997b; Gedl in Oszczypko et al., 2000; Gedl, 2005a). The western boundary of their occurrence runs approximately along the Pińczów meridian: the westernmost occurrence of reworked epicontinental Paleogene specimens is recorded from Gacki (Krzy anowice) and Borków, although the Lower Badenian Korytnica Clays (as well as the underlying fossil-barren clays with lignite), contain no Paleogene taxa; only two specimens of Surculosphaeridium (Gedl, 1996a, fig. 7h), presumably reworked from the Cretaceous, were found (see Gedl, 1996a, p. 213 for discussion).

There is a significant difference between the frequency of reworked specimens from sub-evaporitic and supra-evaporitic strata of the northwestern part of the Carpathian Foredeep. The ones from the sub-evaporitic part of the Miocene sequence are infrequent, commonly they occur as isolated specimens, especially when compared to the rich assemblages of in situ specimens. This contrasts with much more frequent occurrence of reworked Paleogene specimens in supra-evaporitic strata of the northwestern Miocene succession of the Foredeep. The latter occur both in basinal fine detrital deposits (the Upper Badenian-Sarmatian Krakowiec Clays) as well as in the coarse-grained organodetrital rocks of the Roztocze area (Upper Badenian) and the Sarmatian of the southern surrounds of the Holy Cross Mts. This phenomenon may be associated with increased erosion of the Paleogene cover after the mid-Badenian salinity crisis (cf. Oszczypko et al., 2006). But the frequent occurrence of reworked specimens also may be related to a change in the prevailing sedimentary mode, from generally hemipelagic before the salinity crisis to commonly deltaic during the Late Badenian and Sarmatian. This is clearly visible in the Jamnica S119 borehole: samples with an increased ratio of terrestrial elements contain more frequent Paleogene forms (i.e., the upper part of the Krakowiec Clays), whereas samples with "pelagic" palynofacies (middle and upper parts of the Pecten Beds: 244.1-254 m; lowermost part of the Krakowiec Clays: 229.02-242.9 m) contain rare reworked specimens, or none (Gedl, 1999).

Most of the samples studied contain assemblages that can be imprecisely dated as "Eocene-Oligocene" only. However, in a few samples well-dated assemblages have been found, which may be correlated with known marine strata (Fig. 3).

The oldest reworked assemblages represent Middle Eocene (presumably Bartonian) forms found at Roztocze (Józefów quarries). The age of these assemblages allow their correlation with Middle Eocene deposits from the basal part of the Sołokija Graben Eocene, and from the Łukowa 4 borehole. According to Gaździcka (1994), the Sołokija Graben Eocene represents the Bartonian. There are no more precise Middle Eocene age indicators among reworked specimens. This means that the known distribution of marine strata of this age in southeastern Poland is limited to the Sołokija Graben and the vicinity of Łukowa (Fig. 5) whereas reworked species of this age occur in the Miocene of the neighbouring Roztocze area only. This suggests a limited extent of the Middle Eocene (Bartonian) transgression in this area. However, several reworked dinoflagellate cyst species found in the Foredeep farther west may also represent specimens 

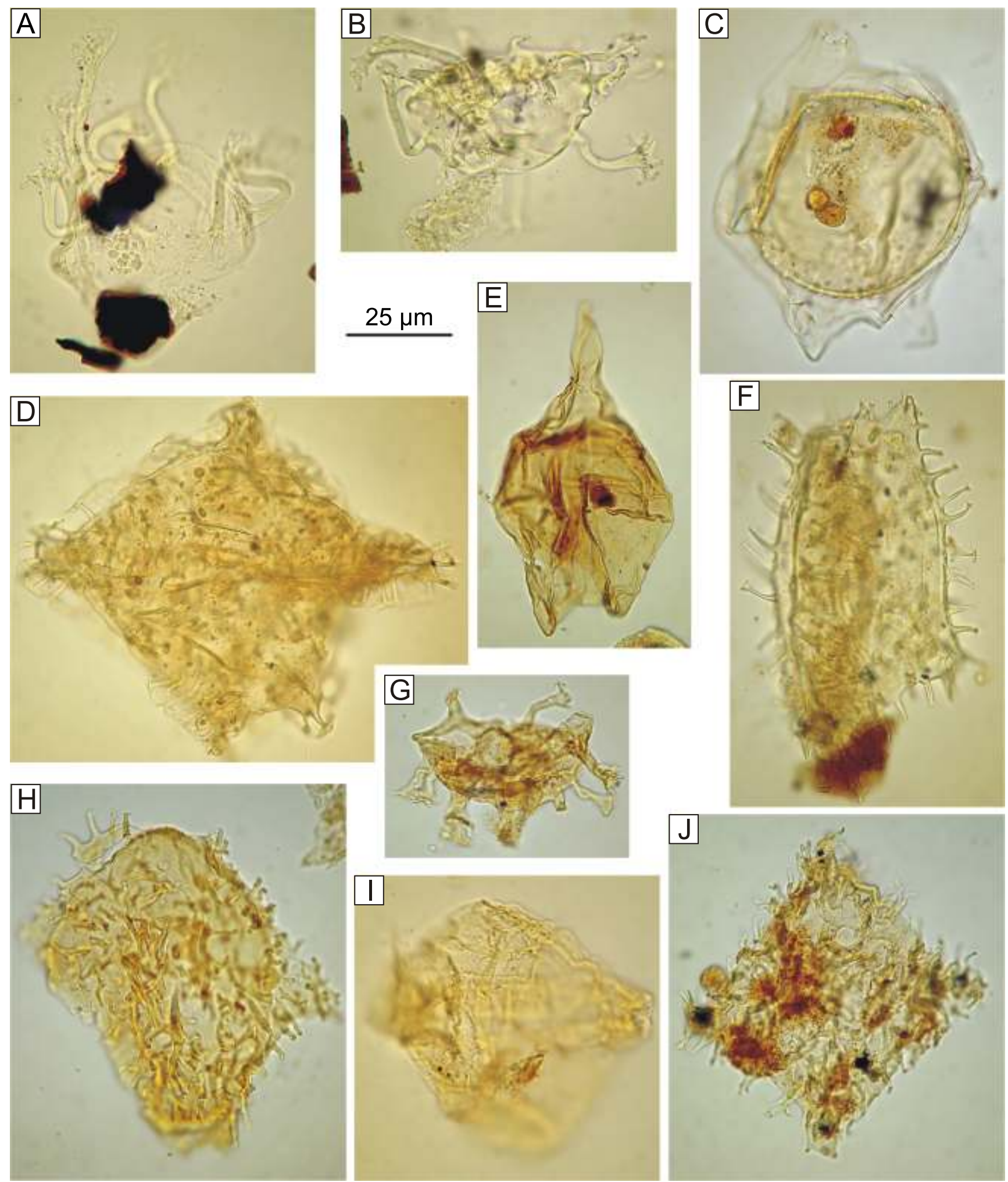

Fig. 4. Reworked dinoflagellate cysts from the Miocene of the Carpathian Foredeep (A-F - specimens from epicontinental deposits; G-J - Carpathians Flysch specimens)

A - Areosphaeridium michoudii (Pardysówka); B - Areosphaeridium michoudii (Pardysówka); C - Deflandrea heterophlycta (Borków); D - Charlesdowniea sp. (Borków); E - Deflandrea sp. (Gacki); F - Wetzeliella sp. (Borków); G - Homotryblium tenuispinosum (Chełm); H - Wetzeliella sp. (Chełm); I - Rhombodinium perforatum (Bęczyn); J - Wetzeliella sp. (Bęczyn) 


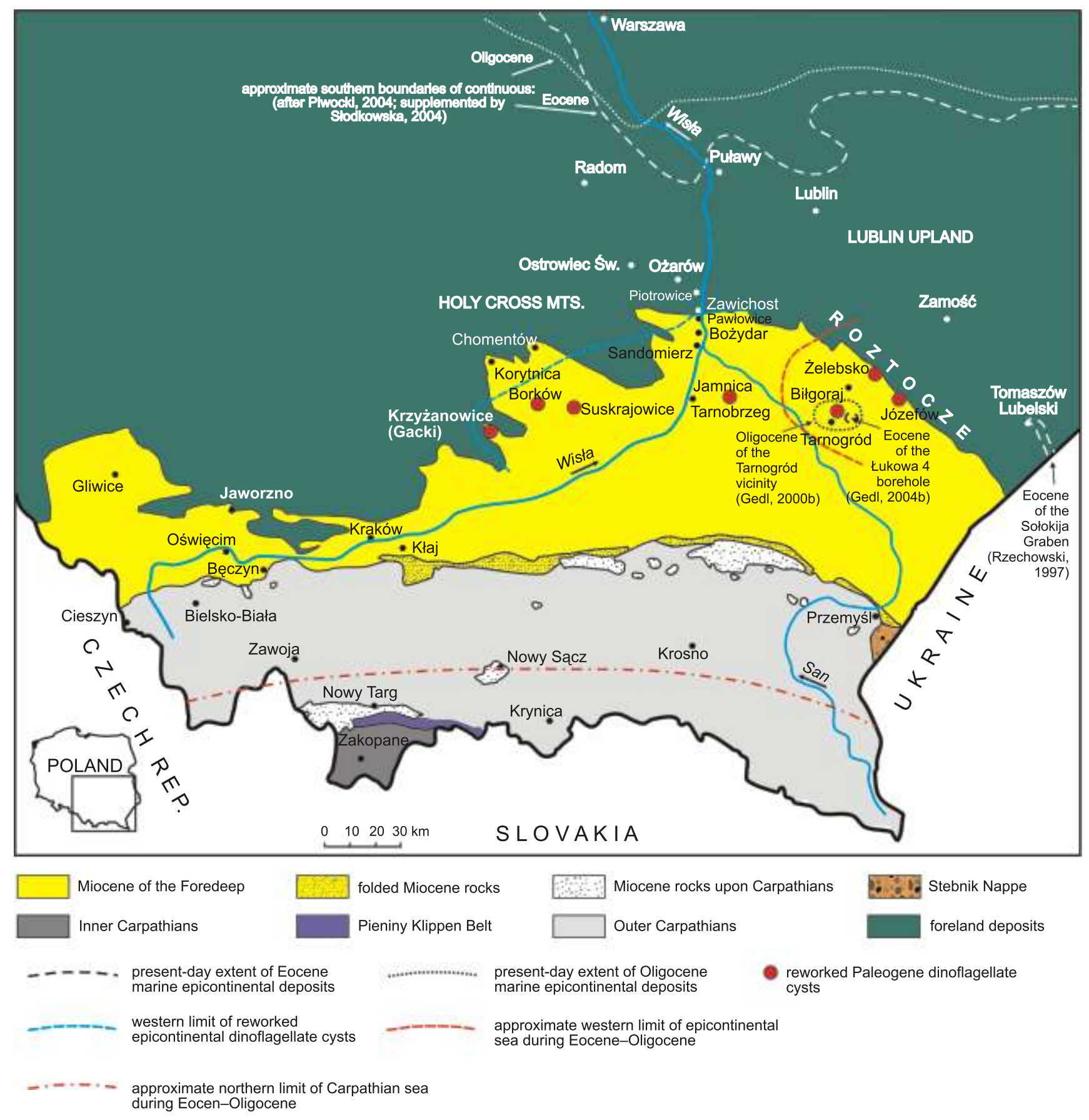

Fig. 5. An attempt at the Eocene-Oligocene palaeogeographical reconstruction of SE Poland on the basis of the extents of palaeontologically documented Paleogene marine epicontinental deposits and the occurrence of reworked epicontinental Eocene-Oligocene dinoflagellate cyst specimens in the Miocene of the Carpathian Foredeep

Approximate northern limit of the Carpathian sea during the Eocene-Oligocene after Kotlarczyk (1985)

derived from Middle Eocene strata (e.g., Areosphaeridium diktyoplokum, Dracodinium sp., Areoligera sp.). Moreover, the topmost part of the Sołokija Graben succession yielded poorly age-diagnostic specimens of Deflandrea, which when found in the Miocene, can be dated as Eocene-Oligocene taxa only.

A similar question refers to the distinction of younger, Priabonian dinoflagellate cysts: most of the reworked Paleogene specimens are also known from Late Eocene. No species restricted to the Priabonian were found in the Miocene deposits. This means that the delineation of the Priabonian transgression in southeastern Poland remains difficult. Marine strata of this age were recognized in the upper part of the Sołokija Graben succession.

Among reworked specimens, the most precisely identifiable Oligocene specimens, represented by species with post-Eocene first appearances such as Chiropteridium sp. or Wetzeliella gochtii. Oligocene specimens were found in the upper part of the Krakowiec Clays of the Jamnica S119 borehole, 
and in the Biłgoraj-Tarnogród area (Sucha Wola 1 borehole); a single specimen was found in Borków.

Most of the reworked Oligocene specimens were thus found in proximity to the in situ epicontinental Oligocene deposits, which occur below the Miocene sequence in the Biłgoraj-Tarnogród area (Gedl, 2000a). This suggests a relatively limited extent of the Oligocene transgression in southeastern Poland. However, a single specimen of Chiropteridium sp. found in Borków, may indicate that the Oligocene marine transgression was much more extensive and reached the Holy Cross Mts area (note: as in the case of reworked Eocene dinoflagellate cysts, distinction of Oligocene specimens in the case of long-ranging species is impossible).

\section{DISCUSSION}

The limitation of reworked specimens to the northeastern part of the Polish Carpathian Foredeep clearly points to a limited range of marine Eocene and Oligocene cover in epicontinental basins in southeastern Poland. The distribution of reworked specimens reflects the stratigraphic extent of source deposits, and also subsequent factors such as sedimentary transport directions. However, sedimentological data suggest a predominantly southwards direction of clastic input into the Foredeep Basin along its northern boundary (e.g., Czapowski and Studencka, 1990, 1996; Jasionowski, 1997, p. 53; Wysocka, 2002).

Reworked Eocene and Oligocene dinoflagellate cysts, which occur in the basal parts of the Miocene sequences in the westernmost part of the Polish Carpathian Foredeep (Zawoja 1 borehole) are of Carpathian origin only. This agrees with the interpretations of several authors (e.g., Moryc, 1989) who point at the Carpathians as the main source area for Miocene sediments in this part of the Carpathian Foredeep. The ages of basal intervals of the Carpathian Foredeep succession in this area seems to be not older than Early Miocene. Oszczypko and Oszczypko-Clowes (2003) documented marine deposits representing the NN1 Calcareous Nannoplankton Zone in the lower part (depth 2324-2333 m) of the "Zebrzydowice Formation" in the Andrychów 6 borehole. According to these authors, underlying conglomerates (the "Andrychów Formation") may also represent the Oligocene although no micropalaeontological evidence for this age was given (Oszczypko and OszczypkoClowes, 2003, fig. 9).

A lack of reworked epicontinental Eocene and Oligocene dinoflagellate cysts in the Kraków-Silesia area suggests that this area was not covered by coeval marine transgressions. This conclusion is supported by the results of earlier studies, which indicated no traces of marine conditions in the Kraków-Silesia area. Indeed, geological and geomorphological studies show that this area was then land. The assumption of prevailing continental conditions here is based on the occurrence of regolith and karst, and also sandy deposits typical of a terrestrial environment (e.g., Gradziński, 1962, 1977; Rutkowski, 1965, 1989; Alexandrowicz, 1969; Błaszak, 1970; Felisiak, 1992; see also Bosák et al., 1979). The lack of palaeontological evidence from these deposits makes their precise dating impossible their deposition must have taken place between the Senonian (the age of the youngest levels ) and the Miocene.
Similarly, no traces of Eocene-Oligocene marine transgression across the Holy Cross Mts. have been noted (Fig. 5). The oldest Cenozoic strata in the southeastern surrounds of the Holy Cross Mts. are represented by continental loamy and phytogenic deposits known from the Chomentów vicinity (Kowalewski, 1927, 1930), and from Ostrowiec and O arów (e.g., Samsonowicz, 1934). In the latter area, Paleogene deposits are preserved locally, mainly as continental deposits, commonly associated with karst (Kosmowska-Suffczyńska, 1966). Also the northern surrounds of the Holy Cross Mts. show no traces of marine deposits of Eocene-Oligocene age. Karaszewski (1966) described, from a few localities south of Radom, locally occurring quartzose and glauconitic deposits. Due to a lack of fossils Karaszewski (1966) questionably interpreted these as traces of marine transgression of Oligocene age. However, his descriptions of these deposits point to their, at least partly, karst origin, and should be thus related to a continental environment. Similar glauconitic deposits with characteristic large quartz pebbles (locally termed "quartz beans") are known from the Puławy area where they rest on Danian gaizes.

The situation in the central part of the foreland between the Holy Cross Mts. and the Roztocze area is in some ways different. Although the Cenozoic succession generally starts there with Miocene strata (e.g., Brzezińska, 1961; Areń, 1971) glauconitic clastic deposits have been discovered in a few places which were arbitrary attributed to the marine Oligocene. An example is "Oligocene" deposits that locally occur on the pre-Cenozoic basement at Trzydnik (Kasiński and Piwocki, 1994, fig. 5). Several other sites of "marine Oligocene" are reported from the Opatówka River valley. Kowalewski (1957) described there an $11 \mathrm{~m}$ thick succession of green to brownish loamy quartz sands from the Bo ydar (also known as Bo y Dar) borehole. These pass into phytogenic deposits dated by Kowalewski (1957) as Lower-lowermost Middle Miocene. Samsonowicz $(1933,1934)$ reported, from the Opatówka River valley and neighbouring Zawichost area the green glauconitic loamy sands known as the Zawichost sands ("piaski zawichojskie" or "piaski zawichoskie"; see Po aryski in Bielecka, 1964). These are also known from nearby Pawłowice (e.g., Kubica, 1965) and Piotrowice where they were exploited in the second half of the 20th century. Similar "green sands" occur also on both sides of the Wisła River where they rest on Upper Cretaceous rocks (e.g., Po aryski, 1951). Czapowski and Peryt (2004) correlated these deposits with the marine Oligocene described by Gedl (2000a) from the Biłgoraj-Tarnogród area. However, in the author's opinion, this correlation is questionable, as the former deposits contain no fossils, whereas the ones from around Tarnogród contain abundant marine phytoplankton fossils. Moreover, they also differ lithologically: marine deposits from Biłgoraj are dark-brown to grey and whitish in the uppermost part, and they contain subordinate amounts of glauconite. The Zawichost sands, in turn, are green, and they contain large amounts of glauconite. The only lithological similarity can be seen between the Biłgoraj sands and the upper part of the sands in the Bo ydar borehole, which are also brownish and contain small amount of glauconite (Kowalewski, 1957).

The northern surrounds of the Polish Carpathian Foredeep, the area of the Holy Cross Mts. and the Sandomierz Upland, have been generally subjected to subaerial erosion at least since 
the Late Cretaceous, when this region was uplifted by the Laramian movements (e.g., Po aryski, 1962). The Danian transgression covered only the northern part of this region. There are no palaeontologically documented Eocene and Oligocene deposits in this area. The only post-Danian deposits are of continental origin, and their age is uncertain due to lack of fossils; they span the Danian-Early Miocene.

It is also difficult to precisely date the erosion of marine Eocene-Oligocene deposits in the eastern part of the Polish Carpathian Foredeep and in Roztocze. Their erosion presumably took place during several phases. There is little known about the pre-Oligocene erosion of older Eocene deposits: Oligocene deposits contain no reworked Eocene fossils which suggests no erosion during the Oligocene transgression. However, the scarcity of in situ Oligocene deposits makes this interpretation highly uncertain. The general preservation of epicontinental Eocene-Oligocene deposits in the Polish Carpathian Foredeep as isolated outcrops suggests that the main phase of erosion took place before the deposition of the oldest Miocene strata (i.e., Lower? or Middle Miocene), i.e., during the Late Oligocene-Early Miocene. The age of this event might be correlated with the time of deposition of the conglomerates and coarse-grained clastic deposits that fill erosional channels in the basement of the western (Moryc, 1989; Oszczypko et al., 2000; Oszczypko and Oszczypko-Clowes, 2003) and eastern (Moryc, 1995) parts of the Carpathian Foredeep, questionably dated as Oligocene-earliest Miocene.

Erosion of Eocene-Oligocene epicontinental deposits on areas not covered by the Miocene sea of the Foredeep Basin continued throughout the whole period of its existence, i.e., during the Badenian and Sarmatian. This presumably increased after general tectonic rebuilding of the Foredeep architecture and subsidence of its basinal part, which took place just after deposition of the evaporitic succession (i.e., during the latest Badenian-earliest Sarmatian; e.g., Krzywiec, 2001). The latter phase of erosion led to almost complete removal of the Eocene-Oligocene cover from the foreland area, leaving only small locally preserved outcrops, mainly in depressions (such as the Sołokija Graben).

\section{CONCLUSIONS}

The occurrence of reworked epicontinental dinoflagellate cysts of Eocene-Oligocene age is limited to the northeastern part of the Miocene of the Polish Carpathian Foredeep. They occur in both sub- and post-evaporitic deposits in this area. Such a distribution likely reflects the extent of marine transgression during the Eocene and Oligocene in SE Poland. Ma- rine strata deposited down during these transgressions were later eroded: according to several authors they served as the source for clastic deposits of the Miocene succession, especially its basal part (e.g., Kowalewski, 1957; Brzezińska, 1961). Deposits of the older, Eocene transgression were possibly at least partly removed by the Oligocene transgression, or during denudation between the Late Eocene and earliest Oligocene. Therefore Eocene forms could be reworked twice, first during the Oligocene transgression, and secondly, from Oligocene sands into the Miocene. This makes precise delimitation of a particular transgression difficult.

The westernmost occurrence of reworked epicontinental Paleogene dinoflagellate cysts shows that marine transgression did not enter the area of the Holy Cross Mts. which, during the Eocene-Oligocene, was land (Fig. 5). This interpretation agrees with the lack of coeval marine deposits across this territory. The only post-Mesozoic-pre-Miocene deposits, regarded by earlier authors as traces of "Oligocene" transgression (e.g., Samsonowicz, 1934), are generally continental deposits associated with karst; there no age indicators of these deposits, which may well be of Paleocene age. However, the occurrence of reworked forms cannot serve as a direct indication of a transgression extent. The latter is documented by in situ deposits found at Roztocze and in the Tarnogród vicinity (Fig. 5).

So far, fossil-documented epicontinental marine deposits in the Carpathian Foredeep and foreland represent at least three transgressive pulses: Middle Eocene, Late Eocene and Early Oligocene (Gaździcka, 1994; Gedl, 2000a; Słodkowska, 2004; Myśliwiec and Śmist, 2006). Their correlation with particular reworked specimens is difficult because most documented reworked forms have long stratigraphic ranges, being known from the Eocene and Oligocene. Nevertheless, the oldest reworked specimens represent Mid-earliest Late Eocene forms, and they occur at Roztocze (Upper Badenian of the Józefów quarries). They may be correlated with Eocene deposits known from the Łukowa 4 borehole and from the lower part of the Eocene succession in the Sołokija Graben.

The youngest reworked assemblages, in turn, are grouped mainly in the northeastern part of the Carpathian Foredeep; they can be linked with the marine in situ Oligocene deposits of the Biłgoraj-Tarnogród area. Rare Oligocene specimens south of the Holy Cross Mts. indicate the extent of the Early Oligocene transgression that reached the eastern parts of this region, but did not cover it.

Acknowledgements. I would like to thank Dr A. Köthe and Dr B. Słodkowska for constructive and critical comments on the manuscript, and Prof. T. Peryt for editorial remarks.

\section{REFERENCES}

ALEXANDROWICZ S. (1958) - Outline of microfaunistic stratigraphy of the Silesian-Cracovian Miocene (in Polish with English summary). Kwart. Geol., 2 (1): 54-81.
ALEXANDROWICZ S. (1961) - Stratigraphy of Chodenice and Grabowiec beds at Chełm on the Raba River (in Polish with English summary). Kwart. Geol., 5 (3): 646-667. 
ALEXANDROWICZ S.W. (1963) - Stratigraphy of the Miocene deposits in the Upper Silesian Basin (in Polish with English summary). Pr. Inst. Geol., 39: 1-130.

ALEXANDROWICZ S.W. (1969) - Couches du Paléogène de la partie méridionale du Plateau de Cracovie (in Polish with French summary). Ann. Soc. Géol. Pol., 39 (4): 681-696.

ALEXANDROWICZ S.W. and PARACHONIAK W. (1956) - Tufity mioceńskie w okolicach Pińczowa nad Nidą. Acta Geol. Pol., 6 (3): 301-325.

ALEXANDROWICZ S.W., GARLICKI A. and RUTKOWSKI J. (1982) Podstawowe jednostki litostratygraficzne miocenu zapadliska przedkarpackiego. Kwart. Geol., 26 (4): 470-471.

AREŃ B. (1971) - The Tertiary of the Góry Świętokrzyskie Region (in Polish with English summary). Pr. Inst. Geol., 64: 107-128.

BAŁUK W. and RADWAŃSKI A. (1977) - Organic communities and facies development of the Korytnica basin (Middle Miocene; Holy Cross Mountains, Central Poland). Acta Geol. Pol., 27 (1): 85-123.

BAŁUK W. and RADWAŃSKI A. (1979) - Additional data on the organic communities and facies development of the Korytnica Basin (Middle Miocene; Holy Cross Mountains, Central Poland). Acta Geol. Pol., 29 (3): 225-238.

BAŁUK W. and RADWAŃSKI A. (1984) - New data on the Korytnica Basin, its organic communities and ecological relationships between species (Middle Miocene; Holy Cross Mountains, Central Poland). Acta Geol. Pol., 34 (3-4): 179-194.

BIELECKA M. (1964) - Szczegółowa Mapa Geologiczna Polski 1:50 000, ark. Zawichost. Wyd. Geol., Warszawa.

BŁASZAK M. (1970) - Description of natural raw materials for moulding mass from the karst sinks of the Częstochowa region (in Polish with English summary). Biul. Inst. Geol., 240: 157-244.

BOSÁK P., GŁAZEK J., GRADZIŃSKI R. and WÓJCIK Z. (1979) - Genesis and age of sediments of the Rudica type in fossil-karst depressions. Čas. miner. geol., 24: 147-154.

BRZEZIŃSKA M. (1961) - The Miocene of the boundary zone between the Western Roztocze (Roztocze zachodnie) and Sandomierz depression (Kotlina Sandomierska) (in Polish with English summary). Biul. Inst. Geol., 158: 5-111.

BUJAK J. and MUDGE D. (1994) - A high-resolution North Sea Eocene dinocyst zonation. J. Geol. Soc., London, 151: 449-462.

BURACZYŃSKI J. (1997) - Roztocze: budowa - rzeźba - krajobraz. Zakład Geogr. Reg. UMCS, Lublin.

BURACZYŃSKI J. and KRZOWSKI Z. (1994) - Middle Eocene in the Sołokija Graben on Roztocze Upland. Geol. Quart., 38 (4): 739-753.

CIEŚLIŃSKI S. and RZECHOWSKI J. (1993) - Mapa geologiczna podło a czwartorzędu Roztocza między Tomaszowem Lubelskim a Hrebennem. In: Tektonika Roztocza i jej aspekty sedymentologiczne, hydrogeologiczne i geomorfologiczno-krajobrazowe (eds. M Harasimiuk, J. Krawczuk and J. Rzechowski): 38-46. Materiały polsko-ukraińskiej konferencji terenowej, Lublin-Lwów, 16-20 czerwca 1993. Lublin.

CZAPOWSKI G. (2004) - Wschodnia część zapadliska. In: Budowa geologiczna Polski, I. Stratygrafia, cz. 3a. Kenozoik. Paleogen. Neogen (eds. T.M. Peryt and M. Piwocki): 239-245. Państw. Inst. Geol.

CZAPOWSKI G. and PERYT T. (2004) - Podstawy stratygrafii: paleogen. In: Budowa geologiczna Polski, I. Stratygrafia, cz. 3a. Kenozoik Paleogen. Neogen (eds. T.M. Peryt and M. Piwocki): 212-213. Państw. Inst. Geol.

CZAPOWSKI G. and STUDENCKA B. (1990) - The sedimentological-palaeontological study of the Lower Sarmatian barrier deposits near Chmielnik (southern border of Holy Cross Mts) (in Polish with English summary). Prz. Geol., 38 (3): 117-127.

CZAPOWSKI G. and STUDENCKA B. (1996) - Regresywne utwory dolnego sarmatu rejonu Chmielnika. V Krajowe Spotkania Sedymentologów - Analiza basenów sedymentacyjnych a nowoczesna sedymentologia - Warszawa-Góry Świętokrzyskie-Ponidzie-Mazowsze, 17-21 czerwca 1996: B27-B33.

De VERTEUIL L. and NORRIS G. (1996) - Miocene dinoflagellate stratigraphy and systematics of Maryland and Virginia. Micropaleont., 42 Supplement: i-viii $+1-172$.
DYBKJÆR K. (2004) - Morphological and abundance variations in Homotryblium-cyst assemblages related to depositional environments; uppermost Oligocene-Lower Miocene, Jylland, Denmark. Palaeogeogr. Palaeoclimatol. Palaeoecol., 206: 41-58.

EATON G.L. (1976) - Dinoflagellate cysts from the Bracklesham Beds (Eocene) of the Isle of Wight, southern England. Brit. Mus. (Nat. Hist.) Geol., Bull., 26: 227-332.

FELISIAK I. (1992) - Oligocene-Early Miocene karst deposits and their importance for recognition of the development of tectonics and relief in the Carpathian Foreland, Kraków region, southern Poland (in Polish with English summary). Ann. Soc. Geol. Pol., 62 (2): 173-207.

GAŹDZICKA E. (1994) - Middle Eocene calcareous nannofossils from the Roztocze region (SE Poland) - their biostratigraphic and palaeogeographic significance. Geol. Quart., 38 (4): 727-734.

GEDL P. (1995) - Batymetryczne zró nicowanie warunków sedymentacji miocenu Przedgórza Karpat na podstawie Dinocyst (Pyrrhophyta). In: Szata roślinna Polski w procesie przemian (eds. Z. Mirek and J.J. Wójcicki): 114. Materiały konferencji i sympozjów 50 Zjazdu Polskiego Towarzystwa Botanicznego, Kraków 26.06-01.07.1995.

GEDL P. (1996a) - Middle Miocene dinoflagellate cysts from the Korytnica clays (Góry Świętokrzyskie Mountains, Poland). Ann. Soc. Geol. Pol., 66 (2): 191-218.

GEDL P. (1996b) - Middle Eocene dinoflagellate cysts from the Rogoźnik section, Flysch Carpathians, Poland. Acta Palaeobot., 35 (2): 195-231.

GEDL P. (1997a) - Palynofacies of the Miocene deposits in the Gliwice area (Upper Silesia, Poland). Bull. Pol. Acad. Sc., Earth Sc., 45 (2-4): 191-201.

GEDL P. (1997b) - Palynological study of an olistolith from the so-called Sucha formation, Zawoja IG-1 borehole (Flysch Carpathians, Poland): age and palaeoenvironment. Ann. Soc. Geol. Pol., 67 (2-3): 203-215.

GEDL P. (1999) - Palaeoenvironmental and sedimentological interpretations of the palynofacies analysis of the Miocene deposits from the Jamnica S-119 borehole (Carpathian Foredeep, Poland). Geol. Quart., 43 (4): 479-492.

GEDL P. (2000a) - Newly found marine Oligocene deposits in the Carpathian Foreland and its palaeogeographic consequences. Slov. Geol. Mag., 6: 155-157.

GEDL P. (2000b) - Biostratigraphy and palaeoenvironment of the Podhale Palaeogene (Inner Carpathians, Poland) in the light of palynological studies. Part II. Summary and systematic descriptions. Studia Geol. Pol., 117: 155-303.

GEDL P. (2004) - Dinoflagellate cyst record of the deep-sea Cretaceous-Tertiary boundary at Uzgruň, Carpathian Mountains, Czech Republic. Geol. Soc., London, Spec. Publ., 230: 257-273.

GEDL P. (2005a) - In situ and recycled dinoflagellate cysts from Middle Miocene deposits at Bęczyn, Carpathian Foredeep, Poland. Stud. Geol. Pol., 124: 371-394.

GEDL P. (2005b) - Late Eocene-early Oligocene organic-walled dinoflagellate cysts from Folusz, Magura Nappe, Polish Carpathians. Acta Palaeobot., 45 (1): 27-83.

GERLACH E. (1961) - Mikrofossilien aus dem Oligozän und Miozän Nordwestdeutschlands, unter besonderer Berücksichtigung der Hystrichosphaeren und Dinoflagellaten. N. Jb. Geol. Paläont., Abh., 112: 143-228.

GRABOWSKA I. and SŁODKOWSKA B. (1993) - Katalog profili osadów trzeciorzędowych opracowanych palinologicznie. Państw. Inst. Geol., Warszawa.

GRADZIŃSKI R. (1962) - Origin and development of subterranean Karst in the southern part of the Cracow Upland (in Polish with English summary). Ann. Soc. Géol. Pol., 32 (4): 429-492.

GRADZIŃSKI R. (1977) - Sedimentation of "moulding sands" on karstified limestone surface in the middle part of Kraków-Wieluń Upland (in Polish with English summary). Pr. Nauk. Uniw. Śl., 185: Kras i speleologia, $1(\mathrm{X})$ : 59-70.

JASIONOWSKI M. (1997) - Lithostratigraphy of the Miocene deposits in the eastern part of the Carpathian Foredeep (in Polish with English summary). Biul. Państw. Inst. Geol., 375: 43-60.

JASIONOWSKI M., PERYT T.M. and CZAPOWSKI G. (2004) Podstawy stratygrafii. Miocen. In: Budowa geologiczna Polski, I. 
Stratygrafia, cz. 3a. Kenozoik. Paleogen. Neogen (eds. T.M. Peryt and M. Piwocki): 213-224. Państw. Inst. Geol.

JASIONOWSKI M., WYSOCKA A. and STUDENCKA B. (2006) - Stop IV - Kamieniołom w elebsku. In: Przebieg i zmienność sedymentacji w basenach przedgórskich (eds. A. Wysocka and M. Jasionowski): 25-27. II Polska Konferencja Sedymentologiczna POKOS2, 20-23.06.2006 r., Zwierzyniec.

KARASZEWSKI W. (1966) - Traces of earlier marine Tertiary in the Ił anka River basin (NE marginal area of the Święty Krzy Mts.) (in Polish with English summary). Kwart. Geol., 10 (1): 153-156.

KASIŃSKI J.R. and PIWOCKI M. (1994) - Neogene coal-forming sedimentation in the Carpathian Foredeep, southern Poland. Geol. Quart., 38 (3): 527-551.

KASIŃSKI J.R. and TOŁKANOWICZ E. (1999) - Amber in the northern Lublin Region - origin and occurrence. In: Investigations into amber. (eds. B. Kosmowska-Ceranowicz and H. Paner): 41-51. Muz. Archeol. w Gdańsku, Gdańsk.

KIRCHNER Z. (1956) - Miocene stratigraphy of the Central Carpathian foreland based on microfaunal studies (in Polish with English summary). Acta Geol. Pol., 6 (4): 421-449.

KITA Z. (1963) - Palynological analysis of Tortonian deposits from the bore-hole Kłaj 1 (East of Kraków) (in Polish with English summary). Ann. Soc. Géol. Pol., 33 (4): 517-526.

KONIOR K. and KRACH W. (1964) - Autochthonous Miocene of the B4 borehole in the West Carpathian Foreland. Bull. Acad. Pol. Sc., Sér. sc. géol. géogr., 12 (3): 181-185.

KOSMOWSKA-CERANOWICZ B. and PO ARYSKA K. (1984) - On new research of Tertiary sediments in Polish Lowlands. Bull. Acad. Pol. Sc., Sér. Sc. Terre, 31 (1-4): 49-58.

KOSMOWSKA-SUFFCZYŃSKA D. (1966) - Tertiary evolution of relief of region of Ostrowiec Świętokrzyski and Ćmielów (in Polish with English summary). Pr. Geogr., 54: 1-114.

KOTLARCZYK J. (1985) - Evolution of the Carpathian tectogene in the Miocene. In: Geotraverse Kraków-Baranów-Rzeszów-Przemyśl-Ustrzyki Dolne-Komańcza-Dukla, Guide to Excursion 4 (ed. J. Kotlarczyk): 21-32. Carpatho-Balkan Geological Association XIII Congress, Cracow, Poland.

KOWALEWSKI K. (1927) - Wyniki badań nad utworami trzeciorzędowemi pd.-wschodniej części arkusza Pińczów. Posiedz. Nauk. Państw. Inst. Geol., 17: 22-26.

KOWALEWSKI K. (1930) - Stratigraphie du MiocPne des environs de Korytnica en comparaison avec le Tertiaire des autres territoires du Massif de Ste-Croix (in Polish with French summary). Spraw. Pol. Inst. Geol., 6: 1-211.

KOWALEWSKI K. (1957) - Tertiaire dans la partie nord de la Basse Plaine de Sandomierz (Pologne meridionale) (in Polish with French summary). Biul. Inst. Geol., 119: 1-124.

KÖTHE A. and PIESKER B. (2007) - Stratigraphic distribution of Paleogene and Miocene dinocysts in Germany. Rev. Paléobiol., 26: 1-39.

KRZOWSKIZ. (1993) - Trzeciorzędowe osady glaukonitowe na Wy ynie Lubelskiej w świetle geochronologii izotopowej glaukonitu. Pr. Nauk. Politechn. Lub., 231: 1-171.

KRZYWIEC P. (2001) - Contrasting tectonic and sedimentary history of the central and eastern parts of the Polish Carpathian Foredeep Basin results of seismic interpretation. Mar. Petrol. Geol., 18: 13-36.

KSIĄ KIEWICZ M. (1951) - Objaśnienia arkusza Wadowice. Ogólna mapa geologiczna Polski w skali 1:50 000. Państw. Inst. Geol.

KUBICA B. (1965) - Odsłonięcie miocenu w Podgórzu koło Zawichostu. In: Przewodnik XXXVIII Zjazdu Polskiego Towarzystwa Geologicznego, Tarnobrzeg 21-24 sierpnia 1965 (ed. S. Pawłowski ): 60-65. Warszawa.

KUCIŃSKI M., NOWAK W. A. and SZOTOWA W. (1975) - Problem stratygrafii utworów mioceńskich w otworach Bielsko 4 (B4) i Kęty 2 (K2). Kwart. Geol., 19 (4): 962-963.

ŁUCZKOWSKA E. (1974) - Profil miocenu w odsłonięciu w Gackach koło Pińczowa. PAN, Oddz. Krak., Spraw. Posiedz. Kom. Nauk., 17: 192-194.

ŁUCZKOWSKA E. (1978) - Faziostratotypen des Badenien. 1. Faziostratotypus: Bohrung Kłaj-1, Karpatische Vortiefe in Polen. In: Chronostratigraphie und Neostratotypen. Miozän der Zentralen
Paratethys (ed. E. Brestenská): 155-158. Band VI: M4 Badenien (Moravien, Wielicien, Kosovien). Bratislava.

ŁUCZKOWSKA E. (1995) - Korelacja biostratygraficzna miocenu Z nowych wierceń w Wieliczce. Geologia, AGH, 21: 255-265.

MACKO S. (1957) - Lower Miocene pollen flora from the valley of Kłodnica near Gliwice (Upper Silesia). Pr. Wroc. Tow. Nauk., Ser. B, 88: $1-314$.

MORYC W. (1989) - Miocen przedgórza Karpat Zachodnich w strefie Bielsko-Kraków. In: Tektonika Karpat i Przedgórza w świetle badań geofizycznych i geologicznych (zagadnienia wybrane); referaty sesji, Kraków, 1989: 170-198.

MORYC W. (1995) - Lądowe utwory paleogenu na obszarze przedgórza Karpat. Nafta-Gaz, 51: 181-195.

MYŚLIWIEC M. and ŚMIST P. (2006) - Eocene and Oligocene sediments of the Tarnogród area (NE part of the Polish Carpathian Foredeep) (in Polish with English summary). Prz. Geol., 54 (8): 724-730.

NEY R. (1968) - The role of the „Cracow bolt” in the geological history of the Carpathian fore-deep and in the distribution of oil and gas deposits (in Polish with English summary). Pr. Geol., 45: 1-82.

NEY R., BURZEWSKI W., BACHLEDA T., GÓRSKI W., JAKUBCZAK K. and SŁUPCZYŃSKI K. (1974) - Outline of paleogeography and evolution of lithology and facies of Miocene layers on the Carpathian Foredeep (in Polish with English summary). Pr. Geol., 82: 3-64.

ODRZYWOLSKA-BIEŃKOWA E., PO ARYSKA K. and MARTINI E. (1978) - Middle Oligocene microfossils from the Polish Lowlands: their stratigraphical and palaeogeographical significance. Acta Palaeont. Pol., 23 (3): 249-291.

OLEWICZ Z. (1973) - Geologia przykarpackiego obszaru między Wieliczką a Bochnią. Pr. Inst. Naft.: 1-76.

OLSZEWSKA B. (1999) - Biostratigraphy of Neogene in the Carpathian Foredeep in the light of new micropalaeontological data (in Polish with English summary). Pr. Państw. Inst. Geol., 168: 9-27.

OSZCZYPKO N. (1996) - The Miocene dynamics of the Carpathian Foredeep in Poland (in Polish with English summary). Prz. Geol., 44 (10): 1007-1019.

OSZCZYPKO N. and OSZCZYPKO-CLOWES M. (2003) - The Aquitanian marine deposits in the basement of the Polish Western Carpathians and its palaeogeographical and palaeotectonic implications. Acta Geol. Pol., 53 (2): 101-122.

OSZCZYPKO N., LUCIŃSKA-ANCZKIEWICZ A., GEDL P. and MALATA E. (2000) - Paleogene autochthonous deposits at the basement of the Polish Outer Carpathians and their paleogeographical implications. Slov. Geol. Mag., 6 (2-3): 143-145.

OSZCZYPKO N., KRZYWIEC P., POPADIUK I. and PERYT T. (2006) Carpathian Foredeep Basin (Poland and Ukraine): its sedimentary, structural, and geodynamic evolution. AAPG Mem., 84: 261-318.

PERYT D. and GEDL P. (2010) - Palaeoenvironmental changes preceding the Middle Miocene Badenian salinity crisis in the northern Polish Carpathian Foredeep Basin inferred from foraminifers and dinoflagellate cysts. Geol. Quart., 54 (4): 487-508.

PERYT T.M., PERYT D., SZARAN J., HAŁAS S. and JASIONOWSKI M. (1998) - Middle Miocene Badenian anhydrite horizon in the Ryszkowa Wola 7 borehole (southeast Poland) (in Polish with English summary). Biul. Państw. Inst. Geol., 379: 61-78.

PILARZ M. (2012) - Stratygrafia mikropaleontologiczna osadów miocenu obszaru krakowsko-oświęcimskiego. Unpubl. Ph.D. thesis, AGH, Kraków.

PIWOCKI M. (2004) - Paleogen. In: Budowa geologiczna Polski, I. Stratygrafia, cz. 3a. Kenozoik. Paleogen. Neogen (eds. T.M. Peryt and M. Piwocki): 22-71. Państw. Inst. Geol.

POWELL A.J. (1992) - Dinoflagellate cysts of the Tertiary System. In: A Stratigraphic Index of Dinoflagellate Cysts (ed. A.J. Powell): 155-249. British Micropalaeontological Society Publication Series, Chapman and Hall, London.

PO ARYSKA K. and LOCKER S. (1971) - Les organismes planctoniques de l'Eocene supérieur de Siemień, Pologne orientale. Rev. Micropaleont., 14: 57-72.

PO ARYSKI W. (1951) - Odwapnione utwory kredowe na północno-wschodnim przedpolu Gór Świętokrzyskich. Biul. Państw. Inst. Geol., 75: 1-70. 
PO ARYSKI W. (1962) - Atlas geologiczny Polski. Zagadnienia stratygraficzno-facjalne, z. 10. Kreda. Inst. Geol., Warszawa.

RADWAŃSKI A. (1969) - Lower Tortonian transgression onto southern slopes of the Holy Cross Mts. (in Polish with English summary). Acta Geol. Pol., 19 (1): 1-164.

RUTKOWSKI J. (1965) - Senonian in the area of Miechów, Southern Poland (in Polish with English summary). Ann. Soc. Géol. Pol., 35 (1): 3-53.

RUTKOWSKI J. (1976) - Detrital Sarmatian deposits on the southern margin of the Holy Cross Mountains (southern Poland) (in Polish with English summary). Pr. Geol., 100: 1-71.

RUTKOWSKI J. (1989) - Geological structure of the Cracow region, South Poland (in Polish with English summary). Prz. Geol., 37: 302-308.

RZECHOWSKI J. (1997) - Trzeciorzęd i czwartorzęd wschodniej części Wy yny Lubelskiej i Roztocza na Mapie geologicznej Polski 1:200 000. Prz. Geol., 45 (11): 1202-1208.

SAMSONOWICZ J. (1933) - Trzeciorzęd nad dolną Opatówką i dolną Koprzywianką. Posiedz. Nauk. Państw. Inst. Geol., 35: 15-18.

SAMSONOWICZ J. (1934) - Objaśnienia arkusza Opatów ogólnej mapy geologicznej Polski w skali 1:100 000. Państw. Inst. Geol., Warszawa.

SŁODKOWSKA B. (2004) - Tertiary palynological record of the Middle Vistula River valley (central Poland) (in Polish with English summary). Prz. Geol., 52 (1): 84-86.

STOVER L.E. and WILLIAMS G.L. (1995) - A revision of the Paleogene dinoflagellate genera Areosphaeridium Eaton 1971 and Enneadocysta Stover and Evitt 1978. Micropaleont., 41: 97-141.

STOVER L.E., BRINKHUIS H., DAMASSA S.P., de VERTEUIL L., HELBY R.J., MONTEIL E., PARTRIDGE A.D., POWELL A.J., RIDING J.B., SMELROR M. and WILLIAMS G.L. (1996) - Mesozoic-Tertiary dinoflagellates, acritarchs and prasinophytes. Am. As. Strat. Palynol. Found., 2: 641-750.
SZYMANKO J. and WÓJCIK K. (1982) - Geology of the Middle Miocene Korytnica basin (southern slopes of the Holy Cross Mts, Central Poland) in the light of geophysical data and photogeological analysis. Acta Geol. Pol., 32 (1-2): 93-108.

UBERNA J.W. (1981) - Upper Eocene phosphate-bearing deposits in northern and eastern Poland. Bull. Acad. Pol. Sc., Sér. Sc. Terre, 29 (1): 81-90.

UBERNA J. and ODRZYWOLSKA-BIEŃKOWA E. (1977) - New localites of the Upper Eocene in northern patrs of the Lublin region (in Polish with English summary). Kwart. Geol., 21 (1): 73-87.

WOŹNY E. (1966) - Eocen z Siemienia koło Parczewa. Kwart. Geol., 10 (3): 843-850.

WYSOCKA A. (2002) - Clastic Badenian deposits and sedimentary environments of the Roztocze Hills across the Polish-Ukrainian border. Acta Geol. Pol., 52 (4): 535-561.

WYSOCKA A. (2006a) - Badenian clastic deposits of the Roztocze Hills area - evolution of sedimentation on the northern outer ramp of the Carpathian Foredeep Basin (in Polish with English summary). Prz. Geol., 54 (5): 430-438.

WYSOCKA A. (2006b) - Stop II - Kamieniołom Pardysówka. In: Przebieg i zmienność sedymentacji w basenach przedgórskich (eds. A. Wysocka and M. Jasionowski): 17-18. II Polska Konferencja Sedymentologiczna POKOS2, 20-23.06.2006 r., Zwierzyniec.

WYSOCKA A., KRZYWIEC P. and MAKSYM A. (2006) - Stop III Kamieniołom Józefów. In: Przebieg i zmienność sedymentacji w basenach przedgórskich (eds. A. Wysocka and M. Jasionowski): 19-24. II Polska Konferencja Sedymentologiczna POKOS2, 20-23.06.2006 r., Zwierzyniec.

ZIEGLER P.A. (1978) - North-Western Europe: tectonics and basin development. Geol. Mijnbouw, 57: 589-626.

\section{APPENDIX 1}

\section{BOREHOLES FROM THE KRAKÓW-OŚWIECIM AREA}

Dąb 4 (Chodenice Beds: sample 22.3-24.3 m; Skawina Beds: samples 60.3-63.3 and 101.9-102.5 m), Chełm Wielki (Skawina Beds: samples 27 and 69 m), Libią 139 (Skawina Beds: samples $21 \mathrm{~m}$ and $38.7 \mathrm{~m}$ ), Jaworzno 5902 (samples 32.6-34.6 m, 26.6-28.6 m, 19.6-21.6 m), Chełm 7 (Skawina Beds: samples 127 m, 67 m; Chodenice Beds: 33 m).

\section{BOREHOLES FROM THE TARNOGRÓD AREA}

Dzików 12 (eight samples: $1048 \mathrm{~m}, 1047 \mathrm{~m}, 1045 \mathrm{~m}$, 946 m, 909 m, 817 m, 737 m, 471 m), Dzików 15 (nine samples: $1091 \mathrm{~m}, 1088 \mathrm{~m}, 1086 \mathrm{~m}, 1071 \mathrm{~m}, 920 \mathrm{~m}, 835 \mathrm{~m}, 732 \mathrm{~m}$, 462 m, 224 m), Dzików 17 (six samples: 1013 m, $1011 \mathrm{~m}$, 1008 m, 952 m, 745 m, 496 m), Jedlinki 2 (ten samples:
1035 m, 1033 m, 1032 m, 1027 m, 1018 m, 1001 m, 865 m, $847 \mathrm{~m}, 806 \mathrm{~m}, 741 \mathrm{~m}$ ), Księ pol 10 (ten samples: $942 \mathrm{~m}$, 865 m, 825 m, 786 m, 752 m, 711 m, 677 m, 607 m, 502 m, $405 \mathrm{~m}$ ), Księ pol 11 (five samples: 915 m, 894 m, 737 m, 540 m, $331 \mathrm{~m}$ ), Księ pol 12 (samples: 905 m, 748 m, 545 m, 335 m), Potok Górny 4 (six samples: 1099 m, 1096 m, 830 m, 810 m, 740 m, 732 m), Potok Górny 5 (six samples: $1131 \mathrm{~m}$, 1124 m, 1102 m, 1004 m, 912 m, 864 m), Sucha Wola 1 (four samples: 1165 m, 755 m, 709 m, 413 m), Wola Obszańska 9 (six samples: 918 m, 822 m, 663 m, 508 m, 352 m, 206 m), Wola Ró aniecka 7 (eleven samples: $1121 \mathrm{~m}, 1120 \mathrm{~m}, 1107 \mathrm{~m}$, 1078 m, 974 m, 870 m, 765 m, 662 m, 558 m, 455 m, 349 m), Wola Ró aniecka 10 (eight samples: 1057 m, 1052 m, 1031 m, 1030 m, 1028 m, 988 m, 937 m, 501 m), Wola Ró aniecka 11 (nine samples: $1067 \mathrm{~m}, 1066 \mathrm{~m}, 1052 \mathrm{~m}, 1051 \mathrm{~m}, 1049 \mathrm{~m}$, 947 m, 940 m, 819 m, 557 m). 